\title{
A falvakban élő fiatalok jövőképe ${ }^{1}$
}

\author{
BIHARI ILDIKÓ ${ }^{2}$
}

\begin{abstract}
ABSZTRAKT
Az ifjúságkutatás eredményei alapján a fiatalok gyakran céltalanok és nehézséget jelent számukra a jövő tervezése. A tanulmányban egy speciális célcsoport, a falvakban élő 19-25 év közötti befejezett iskolai végzettséggel rendelkező fiatalok jövőbeli terveit mutatjuk be egy 2018ban készült kvalitatív kutatás eredményei alapján. Azt vizsgáltuk, hogy a fiatalok hogyan gondolkodnak az iskolai és a munkaerőpiaci karrierpályájukról, valamint a jövőbeli lakóhelyükről. A jövőről alkotott elképzelések alapján a fiatalokat három típusba (tudatos jövőépítő, sodródó, kudarcokat halmozó) soroltuk és az elemzésben az egyes jövókép-mutatókat a vizsgált típusok alapján mutatjuk be. Kitérünk arra is, hogy a fiatalok közötti iskolázottsági különbség és a jelenlegi élethelyzet hogyan befolyásolja a jövőbeli tervek alakulását.
\end{abstract}

KULCSSZAVAK: iskolai karrierpálya, munkaerőpiac, lokalitás, iskolai lemorzsolódás

\section{ABSTRACT}

\section{The vision of young people living in villages}

According to the results of the youth research, young people are often pointless and find it difficult to plan for the future. Based on the results of a qualitative study conducted in 2018, this study presents the future plans of a special target group of young people aged 19-25 living in villages who have completed their education. We looked at how young people think about their career paths at school and in the labor market and also their future residence. Based on their ideas on their future, we classified young people into three types (conscious future builder, drifting, accumulator of failures) and, in the analysis, we present each vision indicator based on the types examined. We will also look at how the educational gap between young people and the current situation in life influence future plans.

KEYWORDS: school career path, labor market, locality, young people, school dropout

${ }^{1}$ A tanulmány megjelenését az EFOP3.6.3-VEKOP-16-2017-00007 - „Tehetségből fiatal kutató” A kutatói életpályát támogató tevékenységek a felsőoktatásban pályázatból biztosított forrás tette lehetővé.

${ }^{2}$ Egyetemi tanársegéd, Debreceni Egyetem, Szociológia és Szociálpolitika Tanszák; doktorandusz, Humán Tudományok Doktori Iskola Szociológia és társadalompolitika doktori program, bihari.ildiko@ arts.unideb.hu 


\section{TEMATIKUS TANULMÁNYOK - KöZségekben élő immobil fiatalok}

\section{Bevezetés}

Hazánkban nagymértékű életkörülménybeli különbségek alakultak ki az egyes településkategóriák között, ami társadalmi egyenlőtlenségekben jelenik meg (Czibere 2012). A '90-es évek elejétől a jövedelmi olló folyamatosan nyílik, majd az évtized második felében az egyenlőtlenség az elért magas szinten stagnál. (Nemes Nagy 2003) A területi jövedelemegyenlőtlenség Budapest és a vidék kettőségével jellemezhető. A polarizációs folyamatok következtében a '90-es évek elején-közepén kialakult egy rögzült térszerkezet, melynek három fő eleme a fóváros és a vidék közötti fejlettségi olló, a Nyugat és Kelet közötti tagoltság, valamint a kistérség és a város-falu mozaikszerűsége (Nemes Nagy 2003). Czibere (2012) tanulmányában felhívja a figyelmet arra, hogy a települések közötti jövedelmi olló szétnyílásának következményei leginkább a falvak lakosságát érintették kedvezőtlenül, a szegénységben élők aránya megnőtt. Jelentős különbség alakult ki az eltérő településeken élők életkörülményeiben és életkilátásban.

A földrajzi elhelyezkedés és az iskolázottság területi egyenlőtlenségre gyakorolt hatásának elemzésekor Nemes Nagy (2003) azt hangsúlyozta, hogy az iskolázottsági folyamatok térbeli jellemzői tekintetében a polarizációs trend kivételesen nem érvényesül, mert a régiók között nagyon markáns különbségek nincsenek - melynek oka, hogy több egyetemi város található a gazdaságilag stagnáló térségekben -, helyette sokkal inkább a települési lejtő a meghatározó. A népesebb városokban a legjobbak az iskolázottsági mutatók, és folyamatosan romlik a várostól a kisebb méretű falvak irányába. A falvakban élő fiatalok lemaradása a továbbtanulás irányát tekintve is nő. A továbbtanulási esélyüket csökkenti, hogy a középfokon továbbtanuló diákok harmada szakiskolát választ, a gimnáziumban tanulmányokat folytató aránya az országos átlagot sem éri el (Kovách 2012). Mindemellett a fiatalok leszakadását, marginalizálódási esélyét növeli, hogy a 15-19 éves korosztály közel 78\%-a tanul és az egyötödük munkanélkülivé válik. A 20-24 éves korosztályban pedig már csak 14\%-uk van bent az iskolarendszerben (Laki 2006: 196). A rövid iskolai pályafutás és az eltérő családi munkaerőpiaci szocializáció növeli a fiatalok esélyegyenlőtlenségét, csökkenti a munkaerőpiaci és a társadalmi integráció esélyét (Kovách 2012).

Czibere (2012) a negyedik hazai nagymintás ifjúságkutatás eredményeit a települési és regionális egyenlőtlenségek a 18-29 éves ifjúsági korosztály körében, a munkaerőpiac, a jövőtervezés és az érvényesülés tükrében vizsgálta. A 2010-es évek elején lebonyolított kutatás eredményei azt mutatják, hogy az iskolázottsági különbségek települési szintű jellemzői alapján a települési lejtő alsó szintjén, a falvakban volt a legalacsonyabb a diplomások (10\%) aránya, az érettségivel nem rendelkezők aránya viszont 54\%. A munkaerőpiaci aktvitás terén pozitívumként elemelte ki, hogy a fiatalok 80\%-a legalább három hónapig munkavállaló volt. Azok, akik pedig még nem álltak munkába, a munkavállalás kezdetét 21 és 25 éves kor között tervezték (Czibere 2012: 52-53). 


\section{TEMATIKUS TANULMÁNYOK - Községekben élő immobil fiatalok}

A fiatalok munkaerőpiaci kiszolgáltatottságának két mutatójaként a határozott idejű szerződést és a zsebbe kapott pénzt nevezi meg. A többségüket alacsonyabb szintű biztonságot nyújtó, határozatlan idejű munkaszerződés keretében foglalkoztatták. A megkérdezettek egyharmada a fizetését részben vagy egészben nem legális formában kapja. A szerző a szubjektív anyagi jólétérzet elemzéséből a megélt jövedelmi szegénység kapcsán kimutatta, hogy minél alacsonyabb kategóriájú a település, annál magasabb azoknak a fiataloknak az aránya, akik a saját véleményük szerint szűkölködnek, illetve nélkülöznek, melynek aránya a falvakban 25\% felett van (Czibere 2012: 63). A fiatalok az ifjúság főbb problémájaként nevezik meg a nem tervezhető jövőt, az egyéni célok hiányát és a munkanélküliség veszélyét, ettől függetlenül inkább gondolják úgy, hogy van esélyük a vágyott munka megszerzésére.

A mikrocenzus 2016-os adatai is megerősítik, hogy az iskolázottsági szint emelkedésével nő a foglalkoztatottság és csökken a munkanélküliek aránya. 2011 és 2016 között minden iskolázottsági szinten nőtt a foglalkoztatottság, de a legjobb munkaerőpiaci pozícióval a közép- és felsőfokú végzettségűek rendelkeznek. A 2016-os adatok alapján a foglalkoztatottak 61\%-a középfokú végzettségű, és az egynegyedük diplomás. A legrosszabb helyzetben az alapfokú végzettséggel sem rendelkezők vannak, annak ellenére, hogy a foglalkoztatottak aránya 27\%-ra emelkedett, de a munkanélküliek aránya még mindig 5,5\% (KSH 2017: 20-21).

Az alacsony iskolai végzettségű, gyenge munkaerőpiaci pozíciójú fiatalok helyzetét tovább rontja, hogy a '90-es évek óta a kistelepüléseken, aprófalvakban csökkent leginkább a munkahelyek száma, főként az észak-alföldi és az észak-magyarországi régiók kisfalvaiban, ahol a foglalkoztatottak száma közel a felére esett vissza. Az elhelyezkedési lehetőséget nehezíti, hogy nem csak a lakóhelyen, hanem a közeli városok munkáltatóinál is csökkent a betölthető állások száma (Kovács 2008). A kedvezőbb életfeltételek és munkavállalás miatt a falusi lakosok egy részének célja a városba költözés és a régiók közötti vándorlás fő motiválójának a munkavállalást nevezik meg (Kovách 2012).

\section{A kutatás módszerei}

A tanulmány a 19-25 év közötti falvakban élő fiatalok jövőbeli terveit mutatja be. A kutatás 2018-ban az MTA Kiválósági Együttmúködési Programja Mobilitás Kutatási Centrum programja keretében a Debreceni Egyetemen zajlott. 2500 fő alatti településeken kutattunk és a befejezett iskolai végzettségű fiatalokat vizsgáltuk. A fiatalok kiválasztásakor feltétel volt, hogy szülők is a faluban éljenek. A kutatás keretében összesen 104 interjú készült, ebből 53 fiatallal és 51 szülővel. Az interjúalanyokat nem valószínűségi mintavétellel választottuk ki. A tanulmány célja, hogy megismerjük, hogyan gondolkodnak a fiatalok a jövőjükről. Feltételezésünk szerint a fiatalok jövőbeni terveit az iskolai végzettség jelentős mértékben befolyásolja. A fiatalok jövő- 


\section{TEMATIKUS TANULMÁNYOK - Községekben élő immobil fiatalok}

beli aspirációit az iskolai karrierpálya, a munkaerőpiaci mobilitás és a lakóhely tükrében vizsgáljuk. Kérdésként merült fel, hogy a fiatalok rendelkeznek-e jövőbeli tervekkel, és ha igen, akkor mely területeken milyen terveket, célokat tűznek ki maguk elé. A jövőbeli tervek között szerepel-e a képzés, továbbtanulás, hogyan gondolkodnak a munkaerőpiaci státuszukról, hol és milyen területen képzelik el a jövő munkahelyét. Melyek azok a fóbb okok, melyek leginkább a településen tartják a fiatalokat, és melyek azok a tényezők, melyek az elköltözés, a mobilitás irányába terelik.

A megkérdezett fiatalok jövőjüket illető elképzeléseik vegyesek. A fiatalokat három fő típusba soroltuk: tudatos jövőépítők, sodródók és kudarcokat halmozók. Tudatos jövőépítőnek nevezzük azokat, akik konkrét célokat és lépéseket tűznek ki maguk elé, a változás hívei, hogy a jövőben boldogulni tudjanak. Főként érettségizettek, illetve diplomások, vagyis a három típus közül a leginkább képzett fiatalok.

A sodródó fiatalok típusba tartozik a fiatalok nagy többsége, a megkérdezettek közel fele. Ők azok a főként középfokú/középiskolai végzettséggel rendelkező fiatalok, akik megelégszenek jelenlegi helyzetükkel, nem akarnak változást.

A kudarcos/kudarcokat halmozó fiatalok azok, akik alacsony iskolai végzettséggel és munkaerőpiaci státusszal rendelkeznek. Jellemzően korai iskolaelhagyók, illetve szakmával, de érettségivel nem rendelkező fiatalok. Nincsenek konkrét terveik, csak álmokat, vágyakat fogalmaznak meg a jobb élet reményében, de nem tesznek érte lépéseket.

\section{Iskolai karrierpálya az immobil falusi fiatalok körében}

A kutatásban résztvevő fiatalok egy kisebb hányada alapfokú, míg a nagytöbbség legalább középfokú iskolai végzettséggel rendelkezik. A középfokú végzettségűek többségének érettségije és szakmája van. A felsőfokú végzettséggel rendelkezők leginkább rövid ciklusú $B A$ vagy osztatlan képzésen vettek részt.

\section{TUDATOS JÖVŐÉPÍTŐ FIATALOK}

A tudatos jövőépítők főként érettségivel és szakmával rendelkező, valamint diplomás fiatalok, a szakmunkás végzettségűek aránya csekély. A középfokú végzettségüek önállóan választottak szakmát, döntésükkel elégedettek. Továbbtanuláskor elsődleges szempont volt, hogy olyan szakmát tanuljanak, amivel a munkaerőpiacon érvényesülni lehet.

„Hát, jó pár szakma volt elöttem, de egyikre sem mondtam volna azt, hogy tudnám is csinálni. Én szakács szerettem volna lenni, de az, hogy hétvégén dolgozzak, és annyit amennyit, meg olyan körülmények között amilyen körülmények között, hát, akkor azt mondtam, hogy na menjünk és munkáljunk fémet. 


\section{TEMATIKUS TANULMÁNYOK - Községekben élő immobil fiatalok}

Úgyhogy a fémipar volt az, ami vezetett és azon belül is a CNC szakma, mert tudtam azt, hogyha valaki jól csinálja, akkor van benne pénz. Azért ez nem egy utolsó szempont volt, meg mást nem is nagyon tudtam volna elképzelni." (21 éves, férfi, szakközép, dolgozik)

A tanulmányaik befejezését követően a továbbtanulás mint alternatíva a többségnél nem jelent meg, sokkal inkább a mielőbbi elhelyezkedés, a pénzszerzés motiválta a fiatalokat. Akik a munkába állás előtt gondolkodtak a diplomaszerzés lehetőségén, véleményük szerint leginkább a lustaságuk, és a gyenge középfokú tanulmányi eredményük tartotta vissza őket a jelentkezéstől.

„Ez nálam lustaság kérdése volt fóképp. Lehetett volna, de úgy éreztem bölcsebb dolog nem, mert ezzel a szakmával (CNC) ha hamarabb elkezdek dolgozni, akkor elörébb juthatok, mintha elmentem volna egyetemre és vagy öszsze jön az élet vagy nem. Mert nagyon sok egyetemistának nem igazán jön össze a dolog. Meg úgy gondoltam, hogy nem bírnék még ki 3,5, 5-5 évet olyan felesleges dolgok tanulásával, ami nem." (21 éves, férfi, szakközép, dolgozik)

A jövőbeli tervek között a felsőfokú tanulmányok folytatása nem szerepel, maximum egy új szakma és az érettségi megszerzése, de az is elenyésző mértékben.

A középfokú végzettséggel rendelkezőkkel ellentétben a diplomások szakválasztását nem a munkaerőpiaci igényekhez és szükségletekhez való igazodás határozta meg. A döntést leginkább az egyén érdeklődési köre, valamint az egyéni adottságok és erősségek befolyásolták.

A diplomások többsége örül, hogy befejezte a tanulmányait, megelégszik a diplomájával és nem gondolkodik újabb diploma vagy egyéb végzettség megszerzésében. A fiatalok egy része a nyelvvizsga hiánya miatt még nem vehette át a diplomáját, számukra ennek pótlása a legfontosabb cél. Az egyetemi tanulmányaik alatt a fiatalok egy része, különféle tanfolyamokon, illetve OKJ képzésen vett részt, és van, aki jelenleg is egy újabb tanfolyamot szeretne elvégezni és abban elhelyezkedni.

„Még azon gondolkoztam, hogy a környezettant kellett volna, de már most úgy vagyok vele, hogy mindegy. Megcsinálom a nyelvvizsgát, aztán meglesz a diplomám. Utána múkörmös suliba jártam, OKJ képzésen elvégeztem a múköröm építôt, mint szakmát. És még szeretnék gyógyszertári asszisztensi OKJ képzésre menni, és aztán még szakasszisztensire. Hát nem tudom mennyire fog ez így összejönni. Remélem sikerül." (23 éves, nő, diploma függőben, munkanélküli)

A tudatos jövőépítők rendelkeznek a legmagasabb iskolai végzettséggel, nagy többségük érettségizett, illetve diplomás fiatal. Csak szakmával, szakmunkás végzettséggel rendelkező alig van. A nemek tekintetében valamivel alacsonyabb a nők 


\section{TEMATIKUS TANULMÁNYOK - Községekben élő immobil fiatalok}

aránya, mint a férfiaké, de a felsőfokú végzettséggel rendelkezők körében magasabb a nők aránya, a férfiak érettségizett szakmával rendelkezők. Azt feltételezzük, hogy minél magasabb a fiatalok iskolai végzettsége, annál inkább jellemző rájuk a tudatos jövőépítés. A jövőbeli tervek között a továbbtanulás, képzés, átképzés kevésbé, sokkal inkább a munka világában való aktivitás szerepel.

\section{SODRÓDÓ FIATALOK}

A sodródó fiatalok nagy többsége középfokú végzettséggel rendelkezik - érettségije és szakmája van, míg vannak, csak szakmával, illetve érettségivel szakma nélküliek is -, a diplomások aránya elenyésző. Egy részük megelégedett azzal, hogy elvégezte az iskolát. Közülük is voltak, akik kísérletet tettek egy másik szakma elsajátítására, de időközben félbehagyták, melynek hátterében leginkább az anyagi okok álltak. De volt olyan fiatal is, akinek az új szakma, az új képzés nem nyerte el a tetszését. A tanulmányok félbehagyását követően mindannyian munkába álltak.

„Ugye (település neve) jártam gimnáziumba, felsőfokút pedig egyetemet kezdtem, de két év után rájöttem, hogy ez nem az én pályám, amit tanultam, mert jogot tanultam, és rá kellett jönnöm sajnos, hogy nem szeretem. És így elmentem dogozni, úgyhogy semmilyen szakmám nincs.” (24 éves, nö, gimnáziumi érettségi, dolgozik)

Egy másik csoportot alkotják a több szakmával rendelkezők, a bizonyítvány halmozók. Részben úgy ítélték meg, hogy egy plusz szakmával jobb eséllyel indulnak a munkaerőpiacon, részben rájöttek arra, hogy pályát tévesztettek, és a bizonyítvány megszerzését követően pályát módosítottak.

A harmadik csoportba azokat a fiatalokat soroltuk, akik középiskolai tanulmányaikat követően elhelyezkedtek, de a szakmájukban továbbképezték magukat vagy érettségit szereztek. Azokat a fiatalokat is idesoroltuk, akik a tanult szakmájukban nem tudtak elhelyezkedni, és abban bíztak, hogy plusz egy szakma javítja a munkaerőpiaci pozíciójukat.

„Mert nem csak egy sima érettségi volt, hanem hát nem fog eszembe jutni. És akkor ott maradtam az iskolába kétéves szakmán. Az kisgyermek és csecsemő gondozói OKJ-s képesítést adott. Azzal megszereztem azt a papírt és akkor nem tudtam elhelyezkedni vele. De még ugye úgy voltam vele, hogy azért csak jó lenne még tanulni valamit. Akkor kerültem el P-on a S. B. mezögazdasági iskolába. Oda is két évig jártam. Ott technikusit kaptam. Mezögazdasági technikusi képesítést." (25 éves, nő, érettségi, dolgozik) 


\section{TEMATIKUS TANULMÁNYOK - Községekben élő immobil fiatalok}

A sodródók nagy többségénél a továbbtanulási szándék nem jellemző, kivéve azoknál a középfokú végzettségűeknél jelent meg, akik jelenleg a lakóhelyükön dolgoznak, de nem a szakmájukban, és szeretnének az adott munkahelyen, vagy az adott településen magasabb pozíciókba kerülni. A képzésben gondolkodók leginkább a rövid idejű képzéseket fontolgatják.

„Na, hát akkor mit kell rólam tudni, 24 éves vagyok, most töltöttem be, egy jó hete. Konyhán dolgozok, pultozok. Szakács szeretnék lenni az elkövetkezendó időkben. Sajnos szakmám az nincs, mivel az egyetemet otthagytam, úgyhogy majd valami esti tagozatot szeretnék nézni..." (24 éves, nő, gimnáziumi érettségi, dolgozik)

Összességében a sodródó fiatalok megelégszenek középfokú végzettségükkel. Szakirányú továbbképzésük, valamint a diploma megszerzése nem jelenik meg a jövőbeli célok között. Tanulmányok folytatásában főként csak azok a középfokú végzettséggel rendelkező fiatal nők gondolkodnak, akik jelenleg a lakóhelyükön dolgoznak és munkahelyüket szeretnék a jövőben is megtartani. A sodródó fiatalokra jellemző, hogy leginkább a rövid idejű képzéseket preferálják.

\section{KUDARCOKAT HALMOZÓ FIATALOK}

A három típuson belül a kudarcokat halmozó fiatalok rendelkeznek a legalacsonyabb iskolai végzettséggel. A kudarcosok kevesebb mint fele középiskolai tanulmányait befejezte, szakmája van. Több mint fele ellenben a középfokú tanulmányaik során 10-11. osztályban lemorzsolódott, melynek fő okaként a gyenge iskolai teljesítményt, a korai gyermekvállalást és a család nehéz anyagi helyzetét nevezték meg. Volt olyan fiatal is, akit a szülők anyagilag az első szakmáig sem tudtak támogatni.

„Hát nekem nyolc általánosom van, itt Kerekibe szereztem, csak nem mentem továbbtanulni kis anyagi problémák miatt nem tudtam tovább menni." (21 éves, férfi, 8 általános, alkalmi munka)

A szülők is gyakran nyolc osztályt végeztek, és van, akiknek a párja is csak az általános iskolai tanulmányait fejezte be. Mindannyian úgy ítélik meg, hogy egy szakmával könnyebben boldogulnának, jobb esélyük lenne a munkaerőpiacon. A fiatal szülők gyermekeiket támogatni szeretnék a szülőkhöz képest magasabb iskolai végzettség megszerzésében, hogy jobb életet biztosítsanak számukra.

„Semmilyen végzettségünk nincs csak a 10 osztályunk, és a párom sem dolgozik csak a közmunkából és ez ami, nem tudja, ebből nem tudunk teljes normá- 


\section{TEMATIKUS TANULMÁNYOK - Községekben élő immobil fiatalok}

lis családot élni, mint az általános emberek mivel nagyon szegények vagyunk és a mindennapokért küzdeni kell. A kislányom, a kisebbik kislányom ő három éves, most kezdte el az óvodát. (...) Tudni kell róla, hogy ez egy nagyon picike kis közösség, ahol vannak. Nagyon sok kis hátrányos kis szegény kisgyerekkel van együtt. A nagyobbik lány ő 8 éves, ő második osztályos és ő most illeszkedik be az iskolába és nagyon szeretném, hogy az ő jövője ne ilyen legyen, mint az édesanyukájáé. És ezért minden erőmmel próbálok neki, próbálom ôt támogatni." (25 éves, nő, 8 általános, dolgozik)

A kudarcos típusba tartozók szinte kivétel nélkül fontosnak tartják a tanulást annak érdekében, hogy a munkaerőpiacon előnyösebb helyzetbe kerüljenek, biztosabb legyen a megélhetésük. A jövőbeli tervek között az alapfokú végzettségűek jellemzően egy szakmát, míg a szakmával rendelkezők egy újabb szakmát, az átképzést, és esetlegesen a szakmai fejlődésüket tartják elképzelhetőnek, de az álmok szintjén az érettségi és felsőoktatás gondolata is megfogalmazódott. Az iskolai végzettséggel kapcsolatos elképzelések leginkább csak pillanatnyi fellángolásként fogalmazódnak meg, vagy a munkába állás idejét szeretnék kitolni. A tanulást fontosnak tartják, de leginkább csak gondolati szinten jelenik meg.

„Hát úgy van, hogy autószerelö lehetséges, de nem tudom, hogy az élet hogy fogja hozni." (21 éves, férfi, szakmunkás, munkanélküli)

A férfiak közül többen említették, hogy még a jogosítvány árát sem tudják öszszegyűjteni. A fiataloknak a család szükségleteinek biztosítása is nehézséget okoz, ezáltal a továbbtanulás háttérbe szorul, nincs rá lehetőségük.

A kallódó, kudarcos életúttal rendelkező fiataloknak van a legalacsonyabb iskolai végzettsége. Alacsony iskolai végzettséggel a munkaerőpiaci lehetőségek is behatároltak, különös tekintettel a kis településeken. Az iskolából lemorzsolódó fiatalok a korai gyermekvállalás és a család nehéz anyagi helyzete miatt gyakran nem tudják középfokú tanulmányaikat befejezni, és ezáltal megpecsételődik a sorsuk a munkaerőpiacon is.

\section{Fiatalok a munka világában, avagy a munkaerőpiaci karrierpálya alakulása}

A fiatalok nagy többsége dolgozik, és az álláskeresők és a háztartásbeliek aránya alacsony. A fiatalok munkaerőpiaci helyzetét vizsgálva kíváncsiak voltunk arra, hogy milyen összefüggés van a fiatalok iskolai végzettsége és a munkaerőpiaci státusza között. Milyennek látják a fiatalok a munkaerőpiaci helyzetüket és milyen munkával kapcsolatos terveik vannak? Mennyire rugalmasak és mobilak munkavállalás terén a falusi fiatalok? 


\section{TEMATIKUS TANULMÁNYOK - KöZségekben élő immobil fiatalok}

\section{TUDATOS JÖVŐÉPÍTŐ FIATALOK}

A tudatos jövőépítők körében az álláskeresők aránya csekély. A biztos megélhetésre törekszenek és pozitívan látják a jövőbeli munkaerőpiaci helyzetüket. Jelentős részük elégedett a munkahelyével és nem tervez munkahelyváltást. Illetve vannak, akik magasabb, előnyösebb pozícióba szeretnének kerülni, akár a meglévő munkahelyükön vagy akár egy új munkahelyen. A fiatalok egy kisebb része ugyanakkor célként nevezte meg, hogy a jövőben saját vállalkozást indítson. Közülük is van, aki már a meglévő családi gazdaságot szeretné továbbfolytatni fóállásban, illetve olyan is, aki még most szeretne létrehozni vállalkozást.

„[E]gy hegesztôt végeztem el, mai napig abban dolgozom, már 3 éve. Mellette méhészkedünk, amit itthol folytatunk. Hát végül is családi gazdaságban. Már így maradt részben rám, mert júliusban nyertem fiatal gazda pályázatot, és akkor most ez irányban fogunk elmenni az elkövetkezendő időszakban.” (20 éves, férfi, szakmunkás, dolgozik)

Van olyan CNC-s fiatal, aki szakmai tapasztalat és gyakorlatszerzést követően tervez egy saját vállalkozást, illetve van olyan fiatal is, akinél még a tervezett cég profilja is hiányzik.

A tudatos jövőépítők között csekély mértékben, de pályakezdő munkanélküli fiatalok is vannak, akik jövőjüket pozitívan látják. Egy részük jelenleg a településen alkalmi munkát végez, illetve van, aki az otthonában a tanult szakmájában feketén dolgozik. Ha találnak munkát, akkor elhelyezkednek, de ha nem jön össze, akkor tanulni szeretnének.

„Volt már ilyen, hogy Nyíregyen kerestek mükörmöst, és aki a sulit csinálta, aki szervezte csinált egy szalont és úgy lett volna, hogy oda megyek dolgozni. Közben kaptam egy másik lehetőséget is, de igazából egyikben sem érte volna meg elhelyezkedni. Mármint így múkörmös, mint alkalmazott, így egyáltalán nem éri meg. Úgyhogy arra jutottam, hogy mégsem megyek. Meg ugye sok volt a hitegetés, úgyhogy így nem sikerült, de nem is bánom. Úgyhogy most itthon dolgozok. Aztán várom, hogy induljon egy olyan suli, ami érdekel. Valameddig még csinálom ezt, hogyha tudom a kettöt együtt csinálni, de ha nem akkor inkább a másikat választanám, mert tudom, hogy ez nem lesz jó hatással sok év alatt az egészségemre."(23 éves, nő, diploma függőben, munkanélküli, de otthon dolgozik)

Volt olyan pályakezdő munkanélküli diplomás fiatal is, aki a tanult szakmában való könnyebb elhelyezkedés és kedvezőbb munkaerőpiaci helyzet megteremtése céljából jogosítványt szerez éppen, hogy a falujából könnyebben bejárhasson a kö- 


\section{TEMATIKUS TANULMÁNYOK - Községekben élő immobil fiatalok}

zeli városba dolgozni. Tapasztalata szerint a faluban munkalehetőség nincs, legfeljebb szezonális munkavégzésére van lehetőség. Megítélése szerint, aki akar, az tud dolgozni, de ahhoz nem szabad csak a falun belül gondolkodni, mert azok gyakran bebetonozott, nyugdíjas állások.

A tudatos jövőépítő fiatalok munkavállalás szempontjából mobilak. Többségük a lakóhelyükhöz közeli városban dolgozik, naponta ingázó munkavállalók, illetve a pályakezdők is a településen kívüli álláslehetőségekben gondolkodnak. A településen munkát végzők előnye, hogy szakmájuknak megfelelő munkát végeznek, melyre a településen van kereslet (pl. pénzügyi előadó, $\mathrm{CNC}$, családi vállalkozásban dolgozó gépész). A külföldi munkavállalási tervek nem jellemzőek.

\section{SODRÓDÓ FIATALOK}

A sodródó fiatalok nagy többsége is dolgozik. A felsőfokú végzettséggel rendelkezők gyakran a tanult szakmájukban helyezkedtek el és jellemző rájuk, hogy legalább egy családtaggal együtt dolgoznak. A jövőben nem tervezik, hogy másik munkahelyet keresnek vagy munkahelyet váltanának. Jelenleg a településen kívül dolgoznak, és a távolabbi munka vállalása egyelőre nem opció.

A középfokú végzettségűek körében csekély mértékben megjelennek az álláskereső fiatalok is (pl. kozmetikus), akik közül többen dolgoznak napi bejelentéssel vagy otthon feketén. A munkaerőpiaci esélyt latolgatva azt tapasztaltuk, hogy nem borúlátóak. Volt olyan fiatal is, aki konkrét állásajánlattal rendelkezett.

Tanulmányokat nem folytató és nem is dolgozó, ideje legnagyobb részét otthon töltő fiatalra is akadt példa. Pályakezdőként 1,5 hónapig a lakóhelyétől távol már vállalt munkát, de nehézséget jelentett számára önmaga ellátása, az önmagáról való gondoskodás, és inkább a kényelmes otthoni szülői ellátás mellett döntött. Munkahelyét otthagyta, hazaköltözött és a településen vagy egy településhez közeli jó munkára vár.

„Rajtam kívül már mindenki elment dolgozni. Én még munkanélküli vagyok, mivel normális munkát nem tudtam találni. Csak ilyen rossz munkákat. Oda meg azért nem megyek el dolgozni. Azért megválogatom, mit csinálok." (21 éves, férfi, érettségi, munkanélküli)

A középfokú végzettségű fiatalok körében valamivel többen dolgoznak nem a tanult szakmájukban, mint szakmájukban. Ugyanakkor függetlenül attól, hogy a szakmában dolgoznak vagy sem, többségük egyelőre nem tervez munkahelyváltást, elégedett a mostani munkahelyével. A munkával kapcsolatos főbb tervek között szerepel, hogy egyrészt minél tovább az adott munkakörben, vagy munkahelyen dolgozzon, részben azért mert szereti, részben, mert megítélése szerint nem kell sokat 


\section{TEMATIKUS TANULMÁNYOK - Községekben élő immobil fiatalok}

dolgozni. Másrészt vannak, akik egy új szakmában, de a lakóhelyen vagy a lakóhelyhez közel terveznek munkát vállalni.

„Attól függ hová vesznek fel. Ha felvesznek óvónőképzőbe szeretném továbbfejleszteni magam és így feljebb lépni a „ranglétrán”. De nem tervezek munkahelyet váltani. Szeretem ezt." (25 éves, nő, érettségi, dolgozik)

A fiatalok nagy többsége a lakóhelyén dolgozik, és a többiek leginkább az adott településhez közeli városban, faluban és naponta ingáznak. A jövőbeli tervek között nem tervezik, hogy sokkal távolabb vállaljanak munkát.

A sodródó fiatalok ugyanakkor azok, akik a tudatos jövőépítőkhöz és a kallódókhoz viszonyítva rövidtávú - néhány hónapos, legfeljebb egy éven belüli -, de külföldi munkatapasztalattal rendelkeznek. A külföldön dolgozók közül senki nem vágyik vissza dolgozni. A külföldi munkavállalás elleni érvek között szerepelt a honvágy, a családtól való hosszú időre való távollét, a munka nehézsége és a városi élet. Akik még nem dolgoztak korábban külföldön, körükben gondolat szintjén felmerült a külföldi munkavállalás, de többségük egyelőre elégedett a jelenlegi környékbeli munkával. Kevesen gondolják úgy, hogy a jövőben szívesen szerencsét próbálnának külföldön.

\section{KUDARCOKAT HALMOZÓ FIATALOK}

A kudarcokat halmozó életúttal rendelkező fiatalok alacsony iskolai végzettséggel és a legrosszabb munkaerőpiaci pozícióval rendelkeznek. Bár a fiatalok egy jelentős részének van munkahelye, de rosszul fizetett, alacsony presztízsű munkakörben dolgoznak (pl. közmunkás, segédmunkás, raktáros, stb.). A nyolc általánossal és a legfeljebb szakmával rendelkezők munkaerőpiaci pozíciója hasonló, hiszen a szakma birtokában lévők sem a végzettségüknek megfelelő munkakörben dolgoznak és a képzettségi szintjüktől alacsonyabb munkakört töltenek be.

„Közfoglalkoztatott vagyok, a mintagazdaságban szinte mindent elvégzek. Árut szállítok az óvodának, koordinálom öket, uborka válogató gépet kezelem, vagy ha a hivatalban van valami munka, azt csinálom." (24 éves, férfi, szakiskola, dolgozik)

A kudarcosok másik csoportja jelenleg hivatalosan nincs jelen a munkaerőpiacon, részben azért, mert munkát keres, részben mert csekély mértékben további tanulmányok folytatásán gondolkodik, vagy éppen gyermeket nevel. A munkanélküli fiatalok közül többen megemlítették, hogy alkalmi munkát, szezonális munkát vé- 


\section{TEMATIKUS TANULMÁNYOK - Községekben élő immobil fiatalok}

geznek. Sőt, egyes vélemények szerint az alkalmi és a szezonális munka is jobb, mint a közmunka.

„Hát, mert ez, ebbe jobban meglehet élni. Több pénz, meg itt hetente fizetnek.” (21 éves, férfi, 8 általános, munkanélküli)

Sem a nyolc osztállyal, sem a szakmával rendelkező fiatalok körében nem szerepel, vagy csupán távlati tervként egy szakma megszerzésének célja, amivel jobban lehetne boldogulni a munka világában. Volt olyan fiatal, aki a kemény fizikai munka helyett könnyebb munkát szeretne magának, amihez legalább egy jogosítványra szüksége lenne, de a család jelenlegi nehéz szociális helyzete miatt nincs rá lehetősége.

Jelenleg a kudarcos életúttal rendelkező dolgozó fiatalok a munkahelyük megtartásában gondolkodnak, és a távolabbi jövőbeli terv része a munkahelyváltás. A munkát egyáltalán nem végző fiatalok (sem bejelentett, sem alkalmi munka) viszont nem tudják pontosan, hogy mit szeretnének csinálni, céltalanok, jelenleg útkeresésben vannak.

„Hát majd... Hát igen, lehet szeretnék majd dolgozni valahol. Vagy tanulni.” (21 éves, nö, 8 osztály, munkanélküli)

A kallódó fiatalok is szükségesnek tartják munka szempontjából a faluból való kimozdulást, de csak településhez közeli munkahelyekben gondolkodnak.

„Hát lényegébe most már nem, hogy most itthon legyek, és akkor 5 km-re menjek el. Most már mindegy szerintem. Már most már én is beláttam, hogy a közelben biztos, hogy nem lesz munkahely olyan, amilyet én szeretnék, úgyhogy menni kellesz arrébb, vagy lehet úgymond összefogni valakivel, hogy beköltözni egy városba, vagy valami hasonló, de." (21 éves, férfi, szakmunkás, munkanélküli)

Volt rá példa, hogy a fiatal a lakóhelyétől távol kapott állásajánlatot, de a távollét miatt nem vállalta.

„Igen, elöfordult. Mert túl sokat kellett volna ott lenni. Nem hetelni mentünk volna, hanem hónapokra." (25 éves, férfi, 8 általános, dolgozik)

A kudarcos életúttal rendelkező fiatalok körében csekély mértékben tartják elképzelhetőnek, hogy a magasabb fizetés, a családi terhek csökkentése céljából a lakóhelytől távolabbi, de az országon belüli, vagy akár külföldi munkát vállaljanak. 


\section{TEMATIKUS TANULMÁNYOK - KöZségekben élő immobil fiatalok}

\section{Maradni vagy menni?}

A fiatalok többsége tősgyökeres és szereti a faluját. A falu előnyét abban látják, hogy a családtagok, rokonok, barátok közel vannak egymáshoz, probléma esetén van kihez fordulni, van kitől segítséget kérni. Falun sok az ismerős, nagyobb az összetartás, erősebbek a szociális kapcsolatok. A fiatalok szeretik a nyugodt, csendes vidéki környezetet. Az előnyök mellett azonban gyakran hátrányként említik, hogy korlátozottak a munkaerőpiaci, kulturális és szórakozási lehetőségek, és ennek következtében egyre nő az elköltöző fiatalok száma. A falu előnyének és hátrányának feltérképezését követően kérdésként merült fel, hogy hogyan gondolkodnak a fiatalok a jövőbeli lakóhelyükről, és a döntésüket milyen főbb tényezők befolyásolják, és mit gondolnak mennyire végleges a döntésük.

A fiatalok nagy többsége úgy gondolja, hogy a településen marad a jövőben is és csak kevesek tervezik, hogy elköltöznek a faluból. Azok szeretnének a településen maradni, akik vagy lehetőséget látnak a faluban, vagy a falu és család szeretete miatt röghöz kötöttek, illetve kényszerből nem látnak reális esélyt a lakóhelyváltásra.

\section{TUDATOS JÖVŐÉPÍTŐ FIATALOK}

A tudatos jövőépítők többsége szeretne elköltözni. A faluban élésre leginkább azok gondolnak lehetőségként, akik szeretik a falut és vagy már a településen dolgoznak jelenleg is vagy ezt tervezik a jövőben. A munkalehetőség melletti fontos érv, hogy a falvakban az ingatlanárak a városi viszonyokhoz képest sokkal kedvezőbbek, megfizethetőbbek.

„Egyrészt a rokonság, ugye a családtagok ott élnek. Másrészt pedig az ingatlanárak alacsonyak (település neve), tekintve egy nagyvároshoz mérten. Továbbá pedig nagyon kevés tényleg a végzettséggel rendelkező személy, tehát ő úgy gondolom, hogy elhelyezkedni el fogok tudni. És van is bennem egyfajta olyan motiváció, hogy segítsek azoknak, akik kilátástalanabbnak látják a helyzetüket is. Így is példát mutathassak azáltal, hogy ott vagyok, helyben vagyok. Fontos a jelenlét." (25 éves, nö, diploma, dolgozik)

A röghöz kötöttek (,falusi vagyok, az is maradok”) megszokásból élnek a faluban, az újat, a változást nehezen fogadják. A hazai pályát nem tervezik elhagyni, részben a család, barátok, részben a munkahely, részben a kertes ház is a településhez köti őket. A fiatalok a város hátrányaként említették, hogy hozzászoktak a vidéki nagy udvarhoz, a házak tágas teréhez. Nehezen viselnék a bezártságot, egy falusi ház árából legfeljebb társasházba tudnának költözni. Volt olyan fiatal is, aki megpróbálta, hogy jobb munkalehetőség miatt egy nagyváros paneljába költözik, de visszaköltözött. Nem a munka miatt, sokkal inkább azért, mert nem tudta megszokni a városi 


\section{TEMATIKUS TANULMÁNYOK - Községekben élő immobil fiatalok}

élet velejáróját. A fiatalok úgy gondolják, hogy a döntésük végleges, esetleg a párválasztás lehet az, ami felülírhatja a terveket.

Akik kényszerből maradnak, azok leginkább az anyagi okokat nevezik meg hátráltató tényezőként, és a család jelenti számukra a biztos pontot. Vannak, akik a lakóhelyen maradást véglegesnek tekintik és vannak, aki egy ideiglenes állapotnak, leginkább addig, amíg nem találnak egy olyan stabil állást, aminek a keresetéből finanszírozni tudják az önálló életet, vagy akár albérletet tudnak megfizetni.

Akik azt tervezik, hogy valamikor majd elkötöznek a településről, problémának vélik, hogy nincs elég munkahely, vagy a szakmájában nem tud elhelyezkedni, egy másik településre, esetleg a nagyvárosba bejárás pedig időigényes. A költözést fontolgatók ez idáig leginkább a biztos támogató családi háttér és a kényszer miatt maradtak helyben. A jelenlegi helyzetüket ideiglenes állapotnak tekintik mindaddig, amíg sikerül önálló egzisztenciát teremteniük, és/vagy az anyagi helyzetük javul.

„Az volt az oka, hogy má' akkor gyüjtöttem egy másik házra. Azért gyüjtöttem a pénzt, mert el szeretnék költözni a jövőben valamikor a szülőházamból. Még mai napig is gyújtöm a pénzt, pedig ez már 5 éve volt."(22 éves, férfi, érettségi, dolgozik)

Amennyiben sikerülne lépniük, egy legközelebbi nagyvároshoz közeli kisvárost vagy falut választanának lakóhelyül. Nem számottevő, de akadt példa arra is, hogy a fiatal a fóvárosba szeretne költözni a jobb lehetőség reményében, de ugyanakkor volt olyan is, aki idős korban megfontolná a nyugodt falusias környezet előnyét és hazatérne a szülőfalujába.

\section{SODRÓDÓ FIATALOK}

A sodródó fiatalok a leginkább azok, akiknek jelenleg a legkisebb a mobilitási hajlandóságuk, a maradás mellett leginkább kényszerből döntöttek. Az anyagiak mellett a maradás melletti érvként szólt az is, hogy a szülő besegít a gyermekkel kapcsolatos feladatok ellátásába, ami nagy könnyebbséget jelent a fiatalok számára, „tökéletes még itt". Az interjúk alapján azt feltételezzük, hogy a fiatalok bázisként számítanak a családtól kapott támogatásra, és ritka volt az olyan fiatal, aki megemlítette, hogy beszáll a kiadások finanszírozásba, a közös teherviselésbe.

Vannak, akik röghöz kötöttek, akiknél a legfőbb visszatartó erőt a család, illetve a barátok, a társaság és a környezet jelenti. Van, aki soha nem is gondolkodott azon, hogy elköltözzön, mert ide született és nem is szeretne ezen változtatni.

A sodródó fiatalok egy része szeret a településen élni, van munkája vagy a településen vagy közel a településhez, a családja is helyben lakik és a családalapítást és a letelepedést is itt tervezi. Ők azok, akik lehetőséget látnak abban, ha a lakóhelyükön 


\section{TEMATIKUS TANULMÁNYOK - Községekben élő immobil fiatalok}

maradnak és leginkább a településen belüli lakóhely változtatásban gondolkodnak. Elköltözni kevesen szeretnének, de akik fontolgatják, azok döntésüket inkább véglegesnek tekintik. Átmenetileg addig maradnak a faluban, amíg a partnerük befejezi tanulmányait, vagy amíg társat vagy munkát találnak maguknak.

\section{KUDARCOKAT HALMOZÓ FIATALOK}

A kallódó fiatalok közül többen gondolkodnak a településen maradásban, és többen a költözésben is. Azok, akik maradnak, a jövőben is a településen szeretnének élni, jól érzik magukat helyben és a döntésüket véglegesnek gondolják. A röghöz kötöttek főként a család és részben a saját ház miatt sem gondolkodnak más alternatívában. A költözni vágyók ellenben főként kényszerből és csak ideiglenesen maradtak a faluban, fóként a nehéz anyagi helyzet, a munka hiánya/munkahely megléte és a szülő támogató segítsége miatt.

„A gyerekek még kicsik és az nekem nagy segítség, hogy anya segít. Csak anya meg apa, akire bármiben számíthatok. A döntés nem végleges, mert nem szeretnék itt maradni. Nem szeretnék már sokáig itt lenni. Nagyon max. még 2 évet." (21 éves, nő, 8 általános)

Volt olyan fiatal is, aki szeretne elköltözni, de úgy gondolja, hogy a faluban ragadt, viszont reménykedik, hogy helyzete még változhat.

\section{Összegzés}

A tanulmány a tudatos jövőépítő, a sodródó, és a kudarcos életúttal rendelkező falusi fiatalok jövőbeli terveit mutatja be az iskola, a munkaerőpiac és a lakóhely tükrében. A Magyar ifjúság 2012 vizsgálat eredményeinek elemzésekor Czibere (2012) megállapította, hogy a fiatalok többségének nincsenek céljai és a jövőt tekintve bizonytalan, amit a jelen kutatás eredményei is megerősítenek. A sodródók és a kudarcos életutat járó fiatalok azok, akiknél leginkább hiányoznak a konkrét célok és a cél eléréséhez vezető lépések. A fiatalok nagy többsége a középfokú tanulmányait sikeresen befejezte, de a felsőfokú végzettségűek aránya alacsony. A középfokú végzettségű fiatalok továbbtanulási tervei között a diplomaszerzés elvétve jelenik meg a célok között, miközben a mikrocenzus 2016-os adatai alapján a felsőfokú végzettségűek körében a legmagasabb a foglalkoztatottsági arány a különböző iskolai végzettségi csoportok között (KSH 2017). Főként a sodródó fiatalok fontolgatják a leginkább, hogy a középfokú végzettségük mellé újabb szakmát szereznek, de nem feltétlenül csak a munkaerőpiaci esélyek növelése céljából, hanem az iskolát egyfajta 


\section{TEMATIKUS TANULMÁNYOK - Községekben élő immobil fiatalok}

„parkolópályának” tekintik, kitolva ezzel az önmaguk ellátásáért felelősséget vállaló felnőttkor kezdetét. A kudarcos életúttal rendelkező fiatalok körében jelent meg a leginkább, hogy a család anyagi erőforrásai miatt olykor a középfokú tanulmányok befejezése is komoly kihívást jelent. A középfokú oktatásból lemorzsolódó fiatalok iskolai reintegrációs esélye kicsi, amit fóként a család anyagi helyzete és/vagy a gyermeknevelés akadályoz.

A sodródó és leginkább a kallódó fiatalok munkaerőpiaci pozíciója rossz. A fiatalok a település negatívumaként említették, hogy a településen belül gyakran nincs lehetőség az elhelyezkedésre, ugyanakkor az álláskeresők, a munkahely váltásban gondolkodók gyakran a lakóhely és a lakóhely közvetlen környezetében lévő munkalehetőségeket keresik. A tudatos pályaépítők azok, akik a legmagasabb iskolai végzettséggel és a legjobb munkaerőpiaci pozícióval rendelkeznek.

Mindhárom vizsgált típus esetében azt tapasztaltuk, hogy a fiatalok többsége munkalehetőség esetén szívesen maradna a településen. Akik viszont menni szeretnének, őket leginkább a munkavállalás motiválja, és leginkább a közeli városba vagy a város melletti kistelepülésre hiánya főként a sodródó és a kallódó fiatalokat gátolja az önálló életkezdésben.

\section{Irodalom}

Czibere I. (2012): Települési és regionális egyenlőtlenségek a 18-29 éves ifjúsági korosztály körében: munkaerőpiac - jövőtervezés - érvényesülés. In: Nagy Á. Székely L. (szerk.): Másodkézből - Magyar ifjúság 2012. https://kutatopont. hu/files/2012/02/Magyar_Ifjusag_2012_MASODKEZBOL.pdf Letöltés ideje: 2019.08.20.

Gazsó F. (2006): Társadalmi struktúra és iskolarendszer. In: Kovách I. (szerk.): Társadalmi metszetek. Napvilág Kiadó, Budapest, 207-227.

KSH (2017): Mikrocenzus 2016. Budapest https://www.ksh.hu/docs/hun/xftp/idoszaki/mikrocenzus2016/mikrocenzus_2016_4.pdf Letöltés ideje: 2019.08.15.

Kovács K. (2008): Kistelepülések lépéskényszerben. In: Váradi M. M. (szerk.): Kistelepülések lépéskényszerben. Új Mandátum Könyvkiadó, MTA Regionális Kutatások Központja, Budapest, 7-28. http://www.rkk.hu/rkk/keti/pdf/kistelepulesek_lepeskenyszerben.pdf Letöltés ideje: 2019.08.15.

Kovách I. (2012): A vidék az ezredfordulón. A jelenkori magyar vidéki társadalom szerkezeti és hatalmi változásai. Argumentum, MTA Társadalomtudományi Kutatóközpont (Szociológiai Intézet), Budapest http://real.mtak.hu/9296/1/Kov\%C3\%A1chImre-A\%20vid\%C3\%A9k\%20az\%20ezredfordul\%C3\%B3n.pdf Letöltés ideje: 2019.08.20. 
www. metszetek.unideb.hu

\section{TEMATIKUS TANULMÁNYOK - KöZségekben élő immobil fiatalok}

Nemes Nagy J. (2003): A fekvés és az iskolázottság hatása a területi egyenlőtlenségekre Magyarországon. In: Fazekas K. (szerk.): Munkaerőpiaci Tükör 2003. MTA Közgazdaságtudományi Kutatóközpont Országos Foglalkoztatási Közalapítvány, Budapest: 133-143. http://econ.core.hu/file/download/mt_2003_hun/egyben. pdf Letöltés ideje: 2019.08.20. 